THE DEMONSTRATION OF SPIROCHETA PALLIDA IN CHRONIC PARENCHYMATOUS ENCEPHALITIS (DEMENTIA PARALYTICA).

BY JAMES MCINTOSH, M.D.ABERD.

Beit Memorial Research Fellow; Late Research Scholar of the Grocers' Company.

AND

PAUL FILDES, M.B., B.C.CANTAB.

Assistant Bacteriologist to the London Hospital.

(From the Bacteriological Laboratory of the London Hospital, Professor William Bulloch, F.R.S.).

IN a previous issue of BRAIN [1] we discussed the relation of dementia paralytica to syphilis, and described how Noguchi and others had succeeded in demonstrating Spirochæta pallida in the brains of such cases. We mentioned that we ourselves had confirmed these findings, and since, so far as we are aware, there has been no detailed publication on the subject in this country, we now give illustrations of the cases referred to by us.

\title{
The Technique of Examination.
}

The brains or fragments of brain were examined fresh, as received by post from Dr. Gettings, of the Wakefield Asylum, by the method of dark-ground illumination. The most satisfactory illuminator is the parabolic condenser of Zeiss, associated with a $\frac{1}{6}$ in. objective (correction collar), and a No. 6 compensating eyepiece. The best source of light is a small arc lamp the rays of which are passed through a spherical condenser filled with water. A small fragment of cortical grey matter about the size of a pin's head is removed from the specimen and broken up in a drop of saline in a watch-glass. The tissue should not be thoroughly emulsified since the specimen will then be too opaque for satisfactory examination. A small quantity of the fluid is placed on a slide and examined.

After five or ten minutes if the examination is negative a new area of the cortex should be taken, and thus a large area of the brain may be investigated. Wherever spirochætes were found that portion 
of the brain was fixed in formalin and stained by Noguchi's modification of Levaditi's method for demonstrating spicochætes in sections. It is clear that the dark-ground technique gives no information as to the relation of the organisms to the surrounding tissues, but it very much facilitates the examination of sections, and almost ensures that spirochætes are present in the fragment selected.

The detection of Spirochxta pallida in sections of the brain is sometimes easy, but often extremely difficult. As will be seen from the accompanying exact drawings the organisms are at times degenerate or atypical, and if such an example is met with in a specimen in which the nerve fibrils have also taken up the silver, it is quite impossible to be certain that the object is a spirochæte. It is only when areas are found in which the fibrils are unstained, or when a focus contains typical as well as atypical spirochætes, that the diagnosis may be made with confidence.

We have therefore found that it is preferable to traverse a section all over rapidly, rather than to try to disclose single spirochætes in unfavourable areas. If this method is adopted, it will usually happen that a focus may be found in one portion of the slide only, and the spirochætes may be so numerous in this focus that they could not be overlooked. It is unusual to find a single spirochæte which is not accompanied by several others in the vicinity.

\section{Notes of the Cases.}

The following details of the cases include short abstracts of the clinical notes communicated by Dr. Gettings :-

Case 1.-W. G., male, aged 30. Duration of symptoms unknown; admitted June 13, 1912, died January 4, 1914. Clinical manifestations of dementia paralytica; grandiose delusions, speech and hands tremulous, pupils dilated and unequal.

Autopsy. - Great excess of subdural fluid. Brain weighed 1,590 grm. Pia increased in vascularity, thickness and opacity ; large arteries atheromatous, grey matter dark and congested, granulations in fourth ventricle.

Microscopic appearances.-Slight cellular infiltration of the pia-arachnoid; general perivascular infiltration of the vessels in the cortex and in the medulla. Plasma-cells are relatively few in the infiltrations, the majority being large mononuclear cells (endothelial). In some places there is a slight occlusion of the small vessels.

Spirochætes.

Dark ground ... Spirochætes very rare, found only in the frontal region.

Sections $\quad \ldots$ None found. 
Case 2.-M. A. H., female, aged 46. Duration of mental symptoms indefinite, said to have had a stroke in June, 1911; admitted August 20, 1913, died January 9, 1914. Pupils equal and contracted; patient had no knowledge of her surroundings or of what was said to her.

Autopsy.-Brain weighed 1,180 grm. Great increase of subdural fluid. Pia thickened, opaque, and adherent. Grey matter slightly atrophic but reddish in appearance, marked granularity of floor of fourth ventricle.

Microscopic appearances. - Marked infiltration of the pia-arachnoid with plasma-cells and lymphocytes; vessels appear to be normal. In the brain there is only a moderate perivascular infiltration, but in a few places it is very marked. No evidence of glial proliferation, pyramidal cells slightly degenerate.

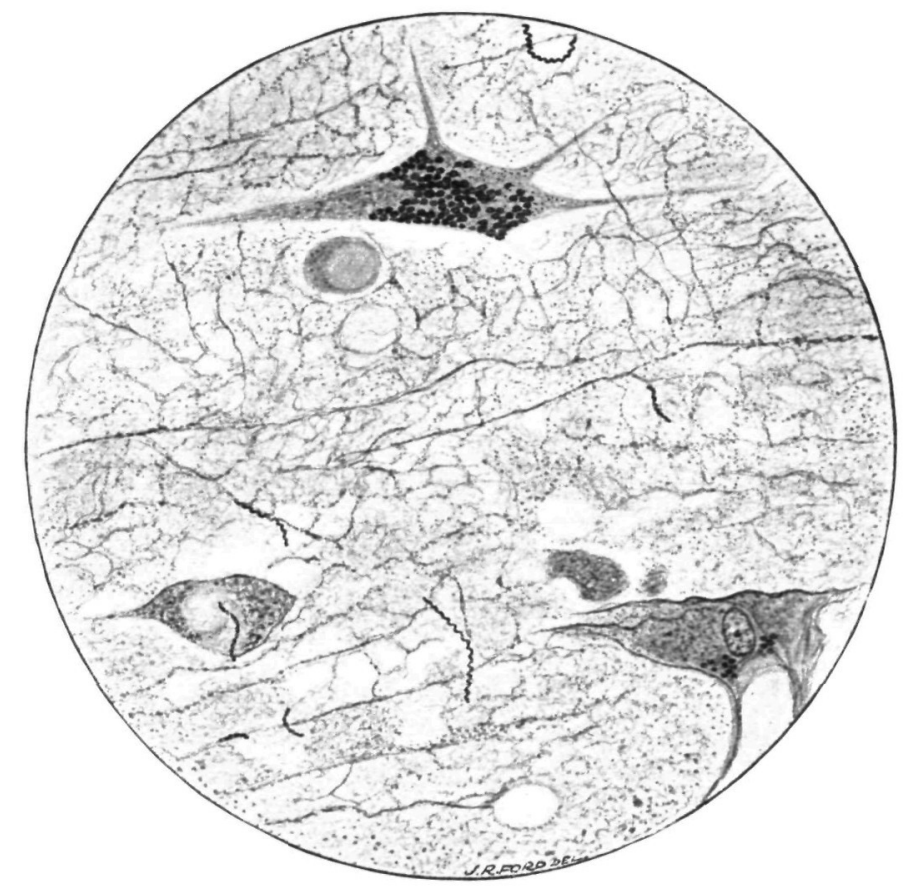

FIG. 1.-Section from frontal region of Case 2 (M. A. H.). Zeiss $\frac{1}{1} \frac{1}{2}$ and No. 6 compensating eyepiece. Noguchi's stain.

Spirochæres.

Dark ground ... Numerous Spirochætæ pallidæ in the frontal and central regions.

Sections... ... Large foci in frontal area, small in the central; spirochætes mainly superficial.

(Vide fig. 1.)

Case 3.-R. M., male, aged 35. Duration of mental symptoms indefinite; stopped work (coal miner) three days before admission; admitted August 3 
1912, died January 13, 1914. Patient was quite demented, and had no knowledge of his surroundings.

Autopsy.-Brain weighed 1,140 grm. Considerable excess of subdural fluid. Pia-arachnoid thickened and opaque, granulations in the fourth ventricle, grey matter very atrophic.

Microscopic appearances.-Meninges here and there show a very slight cellular infiltration. In the brain no distinct perivascular accumulation of cells, though in places there appears to be a slight increase of these cells. The pyramidal cells show much atrophy and degeneration; slight increase of glial cells.

Spirochætes.

Dark ground ... One or two degenerate objects seen, but it was doubtSections ... $\quad \ldots \quad$ None found. ful whether they were spirochrtes or not.

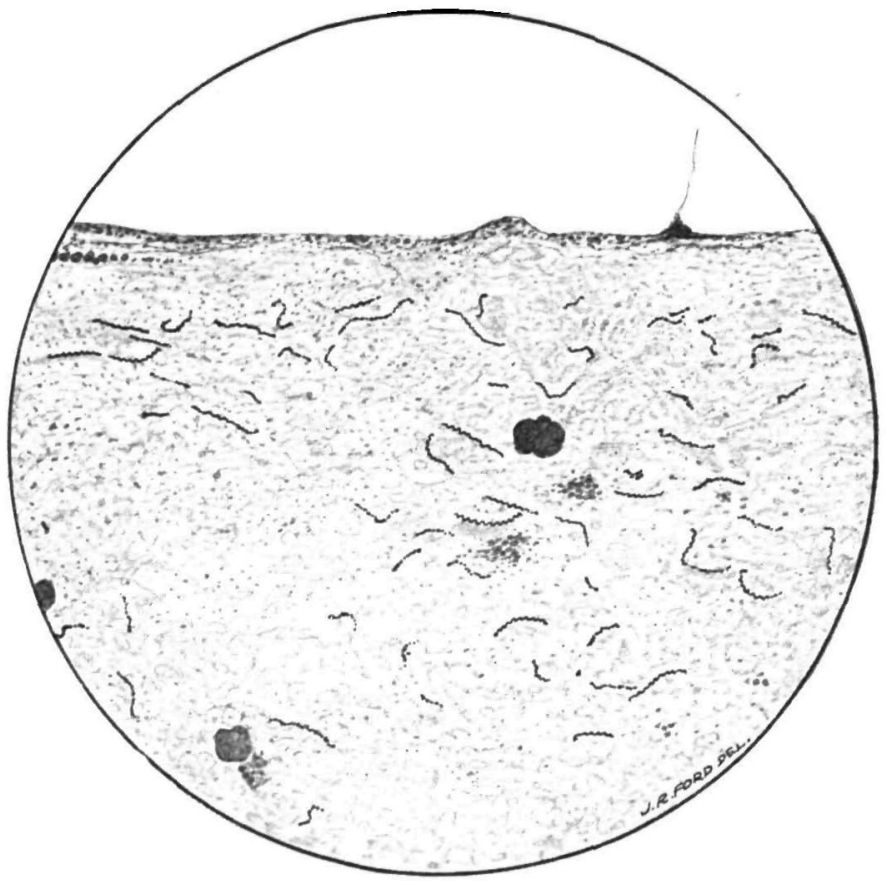

FIG. 2.-Section from frontal region of Case 4 (S. C.).

Case 4.-S. C., female, aged 40. Duration of symptoms, two months; admitted September 24, 1913, died January 13, 1914 . Patient had no interest in her surroundings and was quite demented. She gave birth to a child on October 20,1913, which, however, only lived a day. It had a diffuse cirrhosis of the liver with small-celled infiltration.

Autopsy.-Brain weighed 1,180 grm. Pia-arachnoid thickened and opaque, large arteries atheromatous, grey matter thin and congested, granulations in the fourth ventricle and lateral ventricles. 
Microscopic appearances. - Meninges thickened and odematous, slight infiltration with lymphocytes and plasma-cells, extravasation of red cells, proliferation of the endothelium of the vessels. In the cerebral substance the perivascular infiltration is very slight, the pyramidal cells show some degeneration but are normal in number.

Spirochætes.

Dark ground $\ldots$ Spirochætes very numerous (two or three in each field) in the frontal and central regions.

Sections ... $\quad \ldots$ In places spirochætes very numerous.

(Vide fig. 2.)

Case 5.-J. T., male, aged 47. No previous history obtainable, admitted April 23, 1913, died January 17, 1914. Grandiose delusions ; just before death had several convulsive seizures.

Autopsy.-Brain weighed 1,470 grm. Pia greatly thickened, opaque, and congested. Vessels showed patches of atheroma. On section grey matter yellowish and atrophic. 'Coarse granulations in fourth ventricle.

Microscopic appearances.-Meninges showed a moderate infiltration mostly of mononuclear cells, with a few plasma-cells. In the brain, general perivascular infiltration which included large numbers of plasma-cells.

\section{Spirochætes.}

Dark ground $\ldots$ Spirochætes few in number and rather degenerate.

Sections $\quad \ldots$ None found.

Case 6.-J. T. B., male, aged 34. Duration of mental symptoms three weeks, admitted December 29, 1913, died January 6, 1914. History of syphilis. The clinical diagnosis was "cerebral syphilis," ptosis of left eyelid, left pupil dilated. Patient confused, violent, and resisted any attempt to examine him.

Autopsy.-Brain weighed 1,405 grm. Dura thickened and subdural fluid increased. Pia very vascular and adherent, grey matter congested, granulations along floor of fourth ventricle.

Microscopic appearances.-Marked cellular infiltration of the pia-arachnoid. The blood-vessels were engorged but their walls normal. Perivascular infiltration in the cortex was marked in places; plasma-cells were few in number. No obvious proliferation of neuroglia. Pyramidal cells were considerably shrunken.

\section{Spirochætes.}

Dark ground ... Spirochætes found in the frontal and central areas.

Sections $\quad \ldots$ None found.

Case 7.-A. R., female, aged 46. Duration of mental symptoms three months; admitted October 6,1913, died January 8, 1914. Happy and fatuous; clinical diagnosis "dementia paralytica." Wassermann reaction positive in blood and cerebrospinal fluid.

Autopsy.-Brain weighed 1,140 grm. Enormous increase in subdural fluid, membranes slightly thickened, grey matter paile and atrophic, granulations in the fourth ventricle very marked. 
Microscopic appearances.-Slight cellular infiltration of the pia-arachnoid. Vessels in the cortex showed only a moderate infiltration of their sheaths; though in one or two places it was more pronounced. Infiltration consisted of large mononuclears with a few plasma-cells. Pyramidal cells were decreased while 'glial cells were proliferated.

Spirochætes.

Dark ground ... Numerous spirochætes in the frontal and central and visual areas; most in the frontal regions.

Sections $\quad \ldots$ Several foci with numerous spirochætes in frontal area. (Vide figs. 3 and 4.)

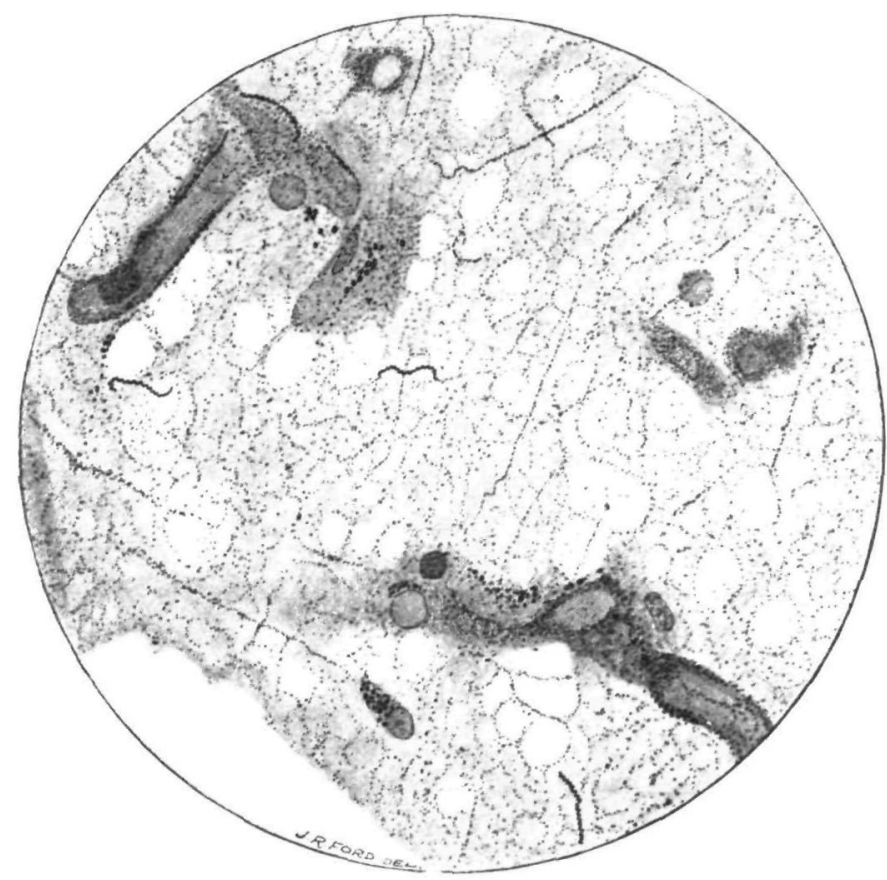

FIG. 3.-Section from frontal lobe of Case 7 (A. R.).

SUMmary.

It will be seen that seven cases of "dementia paralytica" were examined, and that in six of these spirochætes were found by the darkground method, although when sections of these positive cases were cut the organisms were only detected in three. It is thus obvious that the latter method presents much greater difficulties than the former, the spirochætes being found only when they are numerous. Five cases also were examined in which the symptoms suggested a diagnosis of "dementia paralytica." This diagnosis was, however, found on section to be incorrect. No spirochætes were found.

These results do not illustrate the distribution of the spirochætes 
over the whole cortex, because specimens were sent from a few regions only. It was, however, usual to find the organisms in all specimens sent when success was obtained with one.

All the cases examined had exhibited relatively acute manifestations before death, and the brains with one exception were not markedly wasted. The lesions on the whole appeared to be recent.

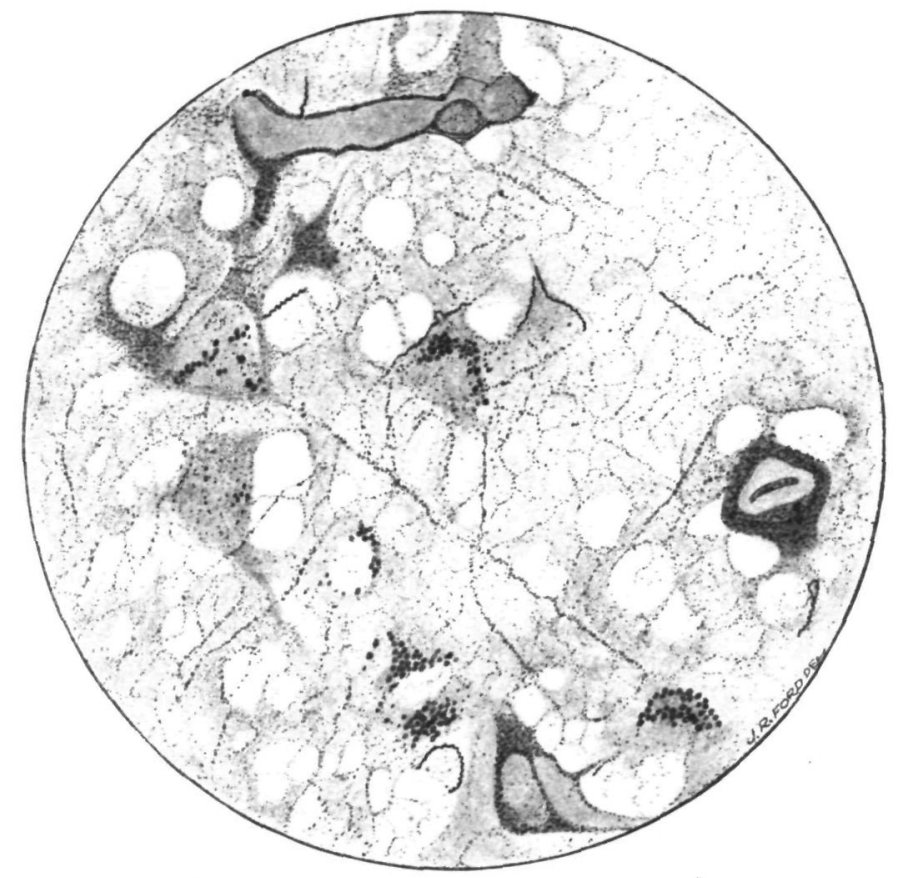

FIG. 4.--Section from frontal lobe of Case 7 (A. R.).

As already mentioned ${ }^{1}$ the spirochætes were always confined to the grey matter; in one case only was a single specimen seen in the meninges. They were more or less superficial, and no constant relation could be observed between them and nerve-cells or bloodvessels. Some spirochætes indeed appeared to be applied to nerve-cells, but this distribution was not striking. Further no connexion was apparent between the organisms and cellular infiltrations; indeed they appeared to be scattered quite fortuitously about the superficial layers of the cortex.

It may be remarked that the drawings by Mr. J. R. Ford give an extremely accurate impression of the appearance of the sections under the microscope.

: Muintozh, J., and Fildes, P. Brain, 1914. 